\title{
Pre- or post-training injection of buspirone impaired retention in the inhibitory avoidance task: involvement of amygdala $5-\mathrm{HT}_{1 \mathrm{~A}}$ receptors
}

\author{
K. C. Liang \\ Department of Psychology, National Taiwan University, 1 Roosevelt Rd., Section 4, Taipei, Taiwan 106 R. O. C.
}

Keywords: emotion, fear conditioning, memory, rats, serotonin

\begin{abstract}
The present study investigated the effect of buspirone on memory formation in an aversive learning task. Male Wistar rats were trained on the inhibitory avoidance task and tested for retention 1 day after training. They received peripheral or intra-amygdala administration of buspirone or other $5-\mathrm{HT}_{1 \mathrm{~A}}$ drugs either before or after training. Results indicated that pretraining systemic injections of buspirone caused a dose-dependent retention deficit; $5.0 \mathrm{mg} / \mathrm{kg}$ had a marked effect and $1.0 \mathrm{mg} / \mathrm{kg}$ had no effect. Post-training injections of the drug caused a time-dependent retention deficit, which was not due to a state-dependent effect on retrieval. When training in the inhibitory avoidance task was divided into a context-training phase and a shock-training phase, buspirone impaired retention only when administered in the shock-training phase, suggesting that the drug influenced memory processing of affective events. Further results indicated that post-training intra-amygdala infusion of buspirone or the $5-\mathrm{HT}_{1 \mathrm{~A}}$ agonist 8 -hydroxy-di- $n$ propylaminotetralin (8-OH-DPAT) caused a time-dependent and dose-dependent retention deficit. Post-training intra-amygdala infusion of the 5- $\mathrm{HT}_{1 \mathrm{~A}}$ antagonist WAY100635 ( $\mathrm{N}$-(2-(4-(2-methoxyphenyl)-1-piperazinyl)- $\mathrm{N}$-(2-pyridyl) cyclohexane carboxamine maleate) attenuated the memory-impairing effects of buspirone. These findings suggest that buspirone may modulate memory storage processes in the inhibitory avoidance task through an action on amygdaloid $5-\mathrm{HT}_{1 \mathrm{~A}}$ receptors.
\end{abstract}

\section{Introduction}

Buspirone is an atypical anxiolytic which shares the antianxiety effect, but not side-effects, with the conventional anxiolytic benzodiazpines (Riblet et al., 1982; Tunnicliff et al., 1991). Studies have shown that buspirone influences behaviour in various animal models of fear and anxiety (Nishimura et al., 1993; Treit et al., 1993; Walker \& Davis, 1997). In addition, buspirone can suppress the anxiogenic effects of various agents including the corticotropin releasing factor (Lazosky \& Britton, 1991) or conditioned fear stimuli (Kehne et al., 1988; Martinez \& Bueno, 1991). Pharmacologically, buspirone has been shown to induce a constellation of actions. It acts as a partial agonist at presynaptic or postsynaptic 5-HT $1 \mathrm{~A}$ receptors (Coplan et al., 1995) or as a $\mathrm{D}_{2}$ antagonist (McMillen et al., 1983). Its metabolite 1-(2pyrimidinyl)-piperazine can block central $\alpha_{2}$ receptors (Giral et al., 1987). These actions have been shown to contribute differentially to the various effects of buspirone on behaviour (Cao \& Li, 1994; Cole \& Rodgers, 1994).

There is accumulating evidence implicating the serotonergic system in learning and memory (Sirvio et al., 1994). Altering the central serotonergic function, either alone or in combination with other neural manipulations, affects performance in various learning tasks (Vanderwolf, 1987; Wenk et al., 1987; Lister et al., 1996). For instance, acute administration of p-chloro-amphetamine before training significantly impaired performance in the inhibitory avoidance task and the radial arm maze, which was due to excessive release of

Correspondence: Dr Keng Chen Liang, as above.

E-mail: kcliang@ms.cc.ntu.edu.tw

Received 20 July 1998, revised 30 November 1998, accepted 2 December 1998 serotonin, as an early effect induced by this drug (Santucci et al., 1996). While other subtypes of 5-HT receptors may also be involved in the effect (Harvey, 1996; Buhot, 1997), extensive evidence suggests that $5-\mathrm{HT}_{1 \mathrm{~A}}$ receptors play an important role in serotonergic modulation of learning and memory; studies have shown that systemic, pretraining injections of $5-\mathrm{HT}_{1 \mathrm{~A}}$ agonists, e.g. flesinoxan or 8 hydroxy-2-(di- $n$-propylamino)tetralin (8-OH-DPAT), impairs acquisition or retention performance in various learning tasks (Carli et al., 1992; Herremans et al., 1995; Kant et al., 1996) or potentiates the subthreshold impairing effect of another amnesic agent (Riekkinen et al., 1995). Conversely, the 5-HT $1 \mathrm{~A}$ antagonist $N$-tert-butyl-3-4-(2methoxyphenyl)piperazin-1-yl-2-phenylpropanamide dihydrochloride (WAY100135) ameliorates the spatial learning deficit caused by scopolamine infused into the hippocampus (Carli et al., 1995b). Another 5- $\mathrm{HT}_{1 \mathrm{~A}}$ antagonist $\mathrm{N}$-(2-(4-(2-methoxyphenyl)-1-piperazinyl)- $N$-(2-pyridyl)cyclohexane carboxamine maleate (WAY100635) can enhance the conditioned stimulus pre-exposure effect in inducing latent inhibition (Killcross et al., 1997a) and attenuate impairments in performing a visuospatial task caused by fornix transection (Harder et al., 1996).

In view of the above evidence, buspirone as a partial $5-\mathrm{HT}_{1 \mathrm{~A}}$ agonist, should have a marked effect on learning and memory. In contrast to the extensive evidence showing an impairing effect of the anxiolytic benzodiazepines on learning and memory (Curran, 1990), not many studies have examined the effect of buspirone on acquisition and/or retention in aversive learning tasks, and the results have been somewhat inconsistent (Korneyev, 1997). Pretraining injections of buspirone have been reported to retard acquisition of avoidance or escape behaviour in some studies (McNaughton \& Morris, 1992; 
Torres et al., 1995) but not in others (Rowan et al., 1990). Likewise, results concerning the effects of buspirone given before testing on memory expression in different types of tasks are not consistent (Kehne et al., 1988; Rowan et al., 1990; Bass et al., 1992; Quartermain et al., 1993).

While an explanation for the above discrepancy was not readily available, it should be pointed out that these studies always administered buspirone either before training or before testing. Thus, the drug could influence performance factors, such as sensorimotor ability or motivation, instead of learning and memory per se. This could complicate the observed results and contribute to the confusing findings. To substantiate the notion that buspirone indeed affects memory processes, it is critical to show an effect of post-training administration of this drug on retention (McGaugh, 1989). Such evidence has not yet been documented in the literature. In view of the evidence that 8-OH-DPAT, administered immediately after training, impaires retention in an inhibitory avoidance task (Carli et al., 1992), it would be interesting to examine whether post-training injections of buspirone also induce a similar memory-impairing effect.

The issue of where in the brain buspirone may act to exert its influences is another issue to be resolved. High densities of 5- $\mathrm{HT}_{1 \mathrm{~A}}$ receptors have been demonstrated in the raphe nucleus, septal region and hippocampus (Pazos \& Palacios, 1985). These areas were found to be involved in the effect of buspirone or 5-HT $1 \mathrm{~A}$ agonists on emotional behaviour elicited by unconditioned or conditioned fear (Lee et al., 1992; Schreiber \& De Vry, 1993; Carli et al., 1995a). Moderate densities of $5-\mathrm{HT}_{1 \mathrm{~A}}$ receptors were also found in the amygdala (Pompeiano et al., 1992). Recent findings indicated that these $5-\mathrm{HT}_{1 \mathrm{~A}}$ receptors in the amygdala were involved in controlling emotional behaviour such as aggression (De Almeida \& Lucion, 1997) or in modulating 5-HT release (Bosker et al., 1997). In view of the evidence implicating the amygdala in memory processing for emotional events (Aggleton, 1992), this study examines whether posttraining infusion of buspirone into the amygdala affects memory in the inhibitory avoidance task and, if it does, whether the effect involves $5-\mathrm{HT}_{1 \mathrm{~A}}$ receptors.

\section{Materials and methods}

\section{Subjects}

Male Wistar rats were used in this study. They were obtained from the National Breeding Center of Experimental Animals (Nankang, Taiwan, ROC). After arriving at our animal facilities, they were housed in individual cages and maintained at $20-25^{\circ} \mathrm{C}$ with $50 \%$ relative humidity. Food and water were available at all times. A $12 \mathrm{~h}$ light : $12 \mathrm{~h}$ dark cycle was adopted with lights on at $07.00 \mathrm{~h}$ throughout the study. When the rats had grown to a body weight of 300-350 g, experiments were performed between $09.00 \mathrm{~h}$ and $13.00 \mathrm{~h}$. This study adhered to Guidelines for Care and Use of Experimental Animals of the National Science Council R.O.C.

\section{Surgery}

One month after arrival, some of the rats received stereotaxic surgery to implant cannulae into the amygdala. After atropine sulphate (Sigma, St Louis, MO, USA) pretreatment $(0.4 \mathrm{mg} / \mathrm{kg}$, i.p.) to prevent respiratory congestion, rats were anaesthetized with an injection of sodium pentobarbital $(45 \mathrm{mg} / \mathrm{kg}$, i.p.; MTC Pharmaceuticals, Cambridge, Ontario, Canada) and mounted on a stereotaxic instrument (David Kopf Instruments, DKI-900, Tujunga, CA, USA). To implant bilateral cannulae into the amygdala, the coordinates were $-3.0 \mathrm{~mm}$ (anterior-posterior), $\pm 4.8 \mathrm{~mm}$ (mediolaterally) and $-7.0 \mathrm{~mm}$ (dorso- ventrally), with the incisor bar set at $-3.3 \mathrm{~mm}$ according to the atlas by Paxinos \& Watson (1997). Cannulae were made of 23-guage stainless steel tubing, with a $0.33-\mathrm{mm}$ inner diameter and a $0.63-\mathrm{mm}$ outer diameter, to a length of $15 \mathrm{~mm}$. Two jewellery screws were implanted over the right frontal and the left posterior cortices, to serve as anchors. The whole assembly was fixed onto the skull with dental cement. An i.m. injection of antibiotic (bicillin, 40000 IU) was given at the end of surgery. Rats were kept warm until recovery from anaesthesia. They recuperated for at least 2 weeks before being subjected to behavioural experiments.

\section{Behavioural task}

Animals of the present study were subjected to the one-trial stepthrough inhibitory avoidance task. In all but one experiment, the training followed a traditional procedure as described elsewhere (Liang et al., 1994). The apparatus was a trough-shape alley divided by a sliding door into a safe compartment and a shock compartment. The safe compartment was lit by a $20-\mathrm{W}$ light bulb and the shock compartment was dark. The rat was placed into the lit side facing away from the door. As the rat turned around, the door was opened. After the rat had stepped to the dark end, the door was closed and an inescapable footshock (1.0 mA for $1.0 \mathrm{~s})$ was administered through a constant-intensity shocker controlled by a timer (Lafayette Instruments, Model 80240 and Model 58010, Lafayette, IN, USA). The shock intensity was calculated as the root mean square of the sinusoidal alternating currents. After administration of the shock, the rat was removed from the alley and returned to its home cage. In the retention test given $24 \mathrm{~h}$ later, the rat was reintroduced into the alley and its latency to step into the dark side was taken as a retention score. If the rat did not step through in $600 \mathrm{~s}$, the test trial was ended and a ceiling score of 600 was assigned.

In an attempt to evaluate whether buspirone had differential effects on various forms of memory, a new inhibitory avoidance training procedure was developed in which two components of the task were isolated to carry, presumably, different types of information. They were administered sequentially such that independent manipulation of memory processing for each component was possible. Briefly, training was divided into two phases that were carried out on two consecutive days. On the first day, designated as context training, rats were put into the alley and allowed free exploration of the lit and the dark sides for 3 min to become acquainted with the spatial configuration of the alley. On the second day, designated as shock training, rats were placed directly into the dark side to receive a 1 $\mathrm{mA} / 1 \mathrm{~s}$ shock. They were tested $24 \mathrm{~h}$ after the shock training. The efficacy of this procedure was examined by testing whether both phases of training were essential to generate avoidance behaviour and whether sequential administration of them yielded retention scores similar to those observed with the traditional one-trial procedure. Next, to assess whether buspirone influenced memory processing of the context or the shock component in the task, different groups of rats were subjected to the two-phase training procedure and, immediately after the context-training phase, the shock-training phase or both, they received injections of vehicle or $5.0 \mathrm{mg} / \mathrm{kg}$ buspirone.

\section{Drugs and drug administration}

Buspirone hydrochloride was obtained from Sigma (St Louis, MO, USA), while 8-OH-DPAT, S(-)UH-301 (S(-)-5-fluoro-8-hydroxy-2dipropylamino-1,2,3,4-tetrahydronaphthalene hydrochloride, a 5$\mathrm{HT}_{1 \mathrm{~A}}$ antagonist) and WAY100635 were obtained from RBI (Natick, MA, USA). For peripheral injections, buspirone was dissolved in distilled water to appropriate concentrations and administered i.p. For 
intra-amygdala infusion, drugs were dissolved in a specific brain buffer which, per $100 \mathrm{~mL}$, contained $0.9 \mathrm{~g}$ of $\mathrm{NaCl}, 4.5 \mathrm{~mL}$ of $0.2 \mathrm{M}$ $\mathrm{Na}_{2} \mathrm{HPO}_{4}$, and $0.95 \mathrm{~mL}$ of $0.2 \mathrm{M} \mathrm{NaH}_{2} \mathrm{PO}_{4} \cdot 2 \mathrm{H}_{2} \mathrm{O}$. All concentrations were calculated as the salt weight. The vehicle for the peripheral injection was water, and that for the central infusion was the specific brain buffer.

The intra-amygdala infusion device was constructed as follows. A piece of $0.5-\mathrm{m}$ polyethylene tubing (Intramedic PE-20, Sparks, MD, USA) was connected to a $10-\mu \mathrm{L}$ microsyringe (Hamilton $701-\mathrm{N}$, Reno, NV, USA) on one end and it was cemented to a 30 guage dental needle on the other. The syringe and the tubing were first filled with distilled water. Drug solutions were then introduced from the injection needle and separated by a tiny air bubble from the distilled water. Drug infusion was administered to a conscious rat shortly before or after training. The rat was held gently and the injection needles were inserted into the cannulae after removing the stylet. Care was taken to minimize stress for the animal. Bilateral intracerebral infusion was administered at a rate of $0.5 \mu \mathrm{L} / \mathrm{min}$ through a syringe pump (Carnegie Medicin, CMA/100, Stockholm, Sweden). The infusion volume on each side was $1.0 \mu \mathrm{L}$. To facilitate drug diffusion, the needle remained in the cannula after infusion for an additional minute before being withdrawn. The stylet was then replaced immediately to prevent back flow.

\section{Histological verification}

After the experiments, animals with amygdala implants were killed with an overdose of sodium pentobarbital $(50 \mathrm{mg}$ per rat, i.p.) and perfused through the heart with physiological saline followed by $10 \%$ formalin. The brain was then removed and stored in formalin for at least $48 \mathrm{~h}$. The brains were sectioned $(40 \mu \mathrm{m})$ and stained with cresyl violet. Placements of the cannulae were examined by projecting the stained slides onto brain atlas charts (Paxinos \& Watson, 1997) to examine the location of cannula tips. Only animals with both cannula tracks within the amygdala were accepted for final data analysis.

\section{Statistics}

In the inhibitory avoidance task the distribution of retention scores was truncated at 600 , therefore medians and interquartile ranges were adopted to represent, respectively, the central and dispersion tendencies of each group unless otherwise stated. The data were analysed by nonparametric Kruskal-Wallis oneway ANOva and followed by paired comparisons with twotailed Mann-Whitney $U$-tests.

\section{Results}

\section{Effects of pretraining injections of buspirone on retention}

To examine the effect of buspirone injected before training on retention, four groups of rats were trained and tested as described above. They received injections of vehicle or $1.0,2.5$ or $5.0 \mathrm{mg} / \mathrm{kg}$ buspirone $30 \mathrm{~min}$ before training. In the training trial, the latencies (mean $\pm \mathrm{SE}$ ) to enter the dark compartment for the vehicle group, and for the 1.0, 2.5 and $5.0 \mathrm{mg} / \mathrm{kg}$ buspirone groups were $22.7 \pm 3.8$, $26.3 \pm 10.0,26.9 \pm 8.0$ and $28.3 \pm 4.7 \mathrm{~s}$, respectively; no significant differences were detected. The 1-day retention scores for various groups are shown in Table 1. They indicate that pretraining systemic injections of buspirone caused a dose-dependent retention deficit; $5.0 \mathrm{mg} / \mathrm{kg}$ impaired retention markedly while $1.0 \mathrm{mg} / \mathrm{kg}$ had no discernable effect. A Kruskal-Wallis oneway ANOVA revealed a significant difference among various groups $\left[H^{\prime}(3)=14.2, P<0.01\right]$. Further paired comparisons indicated that rats receiving $2.5 \mathrm{mg} / \mathrm{kg}$ or $5.0 \mathrm{mg} / \mathrm{kg}$ buspirone had significantly lower retention scores than the
TABLE 1. Effects of pretraining or post-training systemic injections of buspirone on retention

\begin{tabular}{lrlr}
\hline Treatments & $n$ & $\begin{array}{l}\text { Median } \\
\text { score }(\mathrm{s})\end{array}$ & $\begin{array}{l}\text { Interquartile } \\
\text { range (s) }\end{array}$ \\
\hline $\begin{array}{l}\text { Pretraining injections } \\
\quad \text { Vehicle }\end{array}$ & 10 & 600.0 & $600.0-600.0$ \\
$\quad$ Buspirone $1.0 \mathrm{mg} / \mathrm{kg}$ & 9 & 600.0 & $359.1-600.0$ \\
Buspirone $2.5 \mathrm{mg} / \mathrm{kg}$ & 13 & $422.1^{*}$ & $176.7-549.3$ \\
Buspirone $5.0 \mathrm{mg} / \mathrm{kg}$ & 10 & $46.5^{*}$ & $19.3-473.0$ \\
Post-training injections & & & \\
$\quad$ Vehicle & 13 & 600.0 & $573.0-600.0$ \\
Buspirone $1.0 \mathrm{mg} / \mathrm{kg}$ & 13 & 600.0 & $459.6-600.0$ \\
$\quad$ Buspirone $2.5 \mathrm{mg} / \mathrm{kg}$ & 13 & $395.2 \dagger$ & $99.0-600.0$ \\
Buspirone $5.0 \mathrm{mg} / \mathrm{kg}$ & 13 & $210.4 \dagger, \ddagger$ & $76.4-600.0$ \\
Buspirone $5.0 \mathrm{mg} / \mathrm{kg}$ (delayed) & 11 & 600.0 & $600.0-600.0$ \\
\hline
\end{tabular}

$* P<0.01$ different from the pretraining vehicle group; $\uparrow P<0.05$ different from the post-training vehicle group; $\ddagger P<0.05$ different from the delayed buspirone group.

controls $(U=23$ and 14 , respectively; $P<0.01)$. Rats receiving $1.0 \mathrm{mg} / \mathrm{kg}$ buspirone had retention scores not significantly different from the controls but significantly higher than rats receiving $5.0 \mathrm{mg} /$ $\mathrm{kg}$ buspirone $(U=16, P<0.02)$.

\section{Effects of post-training injections of buspirone on retention}

To examine whether post-training injections of buspirone affected retention, five groups of rats were trained on the task, four of them received immediate post-training injections of vehicle, 1.0, 2.5 or $5.0 \mathrm{mg} / \mathrm{kg}$ buspirone and the remaining one received $5.0 \mathrm{mg} / \mathrm{kg}$ of buspirone $4 \mathrm{~h}$ after training. The 1-day retention scores are also shown in Table 1 . The data indicate that post-training systemic injections of buspirone caused a time-dependent and dose-dependent retention deficit; $1.0 \mathrm{mg} / \mathrm{kg}$ of buspirone had no effect on retention, $5.0 \mathrm{mg} / \mathrm{kg}$ injected immediately after training had an impairing effect on retention, yet the same dose injected $4 \mathrm{~h}$ later had little effect. A significant difference was detected among various groups by a oneway ANOVA $\left[H^{\prime}(4)=11.9, P<0.05\right]$. Further paired comparisons indicated no significant difference between the $1.0 \mathrm{mg} / \mathrm{kg}$ buspirone group and the control group. The $2.5 \mathrm{mg} / \mathrm{kg}$ buspirone group had retention scores slightly but significantly lower than the controls $(U=50, P<0.05)$. Rats receiving $5.0 \mathrm{mg} / \mathrm{kg}$ buspirone immediate after training had retention scores significantly lower than both the controls and rats receiving $5.0 \mathrm{mg} / \mathrm{kg}$ buspirone $4 \mathrm{~h}$ after training ( $U=48$ and 36, respectively; $P<0.05$ ), while the latter two groups did not differ from each other.

\section{Lack of state-dependency in the effect of buspirone on retention}

To explore whether the deficits observed above might be due to a state-dependent effect, four groups of rats were used. They received systemic injections of vehicle or $2.5 \mathrm{mg} / \mathrm{kg}$ buspirone either immediately after training or $30 \mathrm{~min}$ before testing and were denoted as the Veh-Veh, Veh-Bus, Bus-Veh or Bus-Bus group according to the types of treatments received (vehicle or buspirone for training-testing). Figure 1 shows the 1-day retention scores. In comparison with the Veh-Veh controls, rats receiving buspirone either after training or before testing showed slightly impaired retention, and rats receiving buspirone in both occasions showed a more pronounced retention deficit, suggesting no state-dependent effect. The differences among the four groups were statistically significant $\left[H^{\prime}(3)=12.9, P<0.01\right]$. Further paired comparisons indicated that, as shown in the previous 


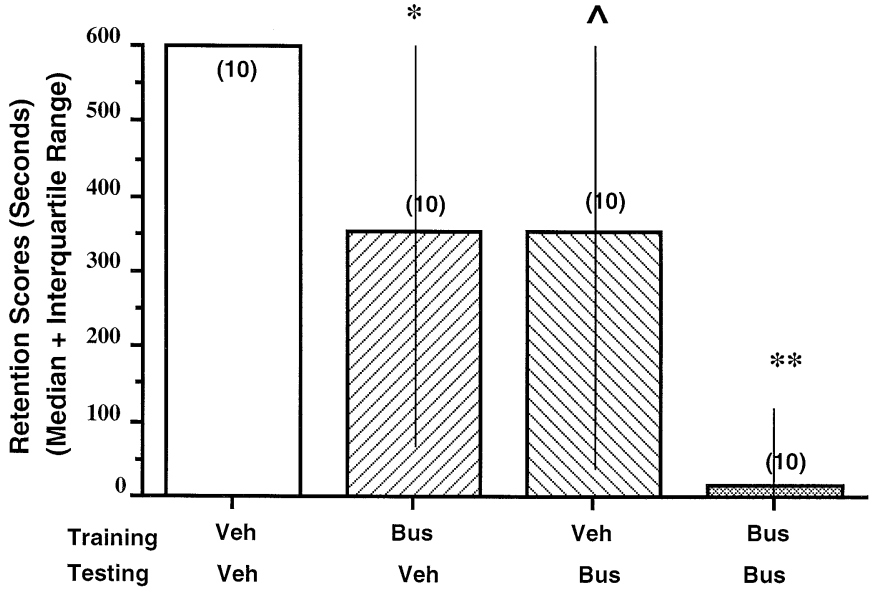

FIG. 1. The effect of buspirone on retention was not state-dependent. Systemic injections of vehicle (Veh) or $2.5 \mathrm{mg} / \mathrm{kg}$ buspirone (Bus) given immediately after training and $30 \mathrm{~min}$ before testing induced a greater retention performance deficit than buspirone given at either occasion alone. ${ }^{\wedge} 0.05<P<0.07$, $* P<0.05 ; * * P<0.01$ different from the Veh/Veh group.

TABLE 2. Retention scores of rats subjected to two-phase training and effects on retention of buspirone injected at either phase of training

\begin{tabular}{llclr}
\hline $\begin{array}{l}\text { Context } \\
\text { training }\end{array}$ & $\begin{array}{l}\text { Shock } \\
\text { training }\end{array}$ & $n$ & $\begin{array}{l}\text { Median } \\
\text { score }(\mathrm{s})\end{array}$ & \multicolumn{1}{c}{$\begin{array}{l}\text { Interquartile } \\
\text { range }(\mathrm{s})\end{array}$} \\
\hline Yes & No & 10 & $18.7^{*}$ & $10.4-39.8$ \\
No & Yes & 10 & $60.6 \dagger$ & $41.6-210.0$ \\
Yes & Yes & 9 & 592.8 & $260.9-600.0$ \\
One-trial control group & 10 & 600.0 & $404.5-600.0$ \\
Vehicle & Vehicle & 12 & 600.0 & $216.3-600.0$ \\
Buspirone & Vehicle & 12 & 408.4 & $228.8-600.0$ \\
Vehicle & Buspirone & 12 & $205.0 \ddagger$ & $62.8-523.1$ \\
Buspirone & Buspirone & 12 & $113.2^{\S}$ & $59.6-162.9$ \\
\hline
\end{tabular}

$* P<0.05, \dagger P<0.01$ different from the one-trial Control group and the Context + Shock groups. $\ddagger P<0.05$ and $\S P<0.01$ different from the Veh/ Veh group.

experiment, post-training injection of buspirone impaired retention (Bus-Veh group versus Veh-Veh group, $U=21, P<0.05$ ). In addition, a pretest injection of buspirone tended to impair retention also, but the effect only approached statistical significance (Veh-Bus group versus Veh-Veh group, $U=26,0.05<P<0.07$ ). Retention was severely impaired by buspirone given at both training and testing: The difference in retention scores between the Bus-Bus group and the Veh-Veh group was significant $(U=12, P<0.01)$, so was that between the Bus-Bus group and the Bus-Veh group $(U=23$, $P<0.05$ ). Yet the difference between the Bus-Bus group and VehBus group only approached statistical significance $(U=26$; $0.05<P<0.07$ ).

\section{Differential effects of buspirone injected at context training and shock training on memory}

Four groups of rats were used to investigate the effectiveness of the two-phase training procedure. The Control group received the traditional one-trial training procedure. The other three groups were subjected to context training alone, shock training alone or both phases of training and were denoted, respectively, as the ContextOnly, Shock-Only or Context-Shock group. Results shown in Table 2 indicate that rats receiving both phases of training in the two-phase procedure had retention similar to that in rats trained with the traditional procedure; omitting either phase of training resulted in
TABLE 3. Effects of post-training intra-amygdala infusion of buspirone or S(-)-UH-301 on retention

\begin{tabular}{lrlc}
\hline Treatments & $n$ & $\begin{array}{l}\text { Median } \\
\text { score }(\mathrm{s})\end{array}$ & $\begin{array}{l}\text { Interquartile } \\
\text { range (s) }\end{array}$ \\
\hline Vehicle & 13 & 222.2 & $131.2-353.7$ \\
Buspirone $1.0 \mu \mathrm{g}$ (immediate) & 9 & 214.1 & $45.6-495.5$ \\
Buspirone $2.5 \mu \mathrm{g}$ (immediate) & 10 & $8.7 *$ & $3.9-77.6$ \\
Buspirone $2.5 \mu \mathrm{g}$ (delayed) & 10 & 160.6 & $50.4-214.5$ \\
S(-)UH-301 $2.5 \mu \mathrm{g}$ (immediate) & 12 & $388.2 \dagger$ & $237.7-537.8$ \\
Buspirone $2.5 \mu \mathrm{g}+\mathrm{S}(-) \mathrm{UH}-3012.5 \mu \mathrm{g}$ & 11 & $113.5 \ddagger$ & $62.8-251.6$ \\
\hline
\end{tabular}

$* P<0.001$ different from the vehicle group and buspirone $2.5 \mu \mathrm{g}$ (delay) group; $\dagger 0.5<P<0.10$ different from the vehicle group; $\ddagger P<0.01$ different from the buspirone $2.5 \mu \mathrm{g}$ group.

poor retention performance. A oneway ANOVA revealed a significant difference among the groups $\left[H^{\prime}(3)=25.5, P<0.001\right]$. Further paired comparisons indicated that the Context-Shock group did not differ from the Control group in retention $(U=35, P>0.1)$. On the other hand, the Context-Only group and the Shock-Only group had retention scores lower than the Control group $(U=0$ and 15 , respectively, $P<0.001$ and 0.01$)$ and also lower than the ContextShock group ( $U=0$ and 15 , respectively, $P<0.001$ and 0.05 ).

To examine possible differential effects of buspirone on memory of the context and memory of the shock, four groups of naive rats were subjected to the two-phase training procedure and injected with either vehicle or buspirone after each phase of training. They were abbreviated as the Veh/Veh, Bus/Veh, Veh/Bus and Bus/Bus groups to denote the treatments received at the context/shock-training phase. The results shown in Table 2 indicate again that the Veh/Veh group trained with a two-phase procedure showed good retention. Buspirone given at the context-training phase did not affect retention, but that given at the shock-training phase alone or at both phases produced a profound impairing effect. A oneway ANOVA revealed significant differences among the groups $\left(H^{\prime}(3)=10.4, P<0.05\right)$. Further paired comparisons indicated that the Veh/Veh group had retention scores better than the Veh/Bus and the Bus/Bus groups $(U=37$ and 26, respectively; $P<0.05$ and 0.01 ), while the latter two groups did not differ from each other. Retention scores of the Bus/Veh group were not different from those of the Veh/Veh group, but they were significantly better than those of the Bus/Bus group $(U=33$, $P<0.05)$. These findings indicate that the effect of buspirone on retention was mainly related to blocking memory processing of the shock.

\section{Effects of post-training intra-amygdala infusion of buspirone on retention}

Six groups of rats with cannulae implanted in the amygdala were trained and tested. Immediately after training, five of them received intra-amygdala infusion of vehicle, or 1.0 or $2.5 \mu \mathrm{g}$ of buspirone, $2.5 \mu \mathrm{g} \mathrm{S}(-) \mathrm{UH}-301$ or $2.5 \mu \mathrm{g}$ buspirone plus $2.5 \mu \mathrm{g} \mathrm{S}(-) \mathrm{UH}-301$. The sixth group received intra-amygdala infusion of $2.5 \mu \mathrm{g}$ buspirone $4 \mathrm{~h}$ after training. The 1-day retention is shown in Table 3. Rats that received intra-amygdala infusion of vehicle showed moderate retention. Post-training intra-amygdala infusion of buspirone still induced a time-dependent and dose-dependent retention deficit and the deficit was attenuated, at least partially, by simultaneous infusion of the 5$\mathrm{HT}_{1 \mathrm{~A}}$ antagonist $\mathrm{S}(-) \mathrm{UH}-301$. A oneway ANOVA found significant differences among the groups $\left[H^{\prime}(5)=24.75, P<0.0002\right]$. Paired comparisons indicated that rats receiving $2.5 \mu \mathrm{g}$ buspirone immediately after training had significantly lower retention scores than the controls $(U=8, P<0.0005)$ or rats receiving $2.5 \mu \mathrm{g}$ buspirone $4 \mathrm{~h}$ 


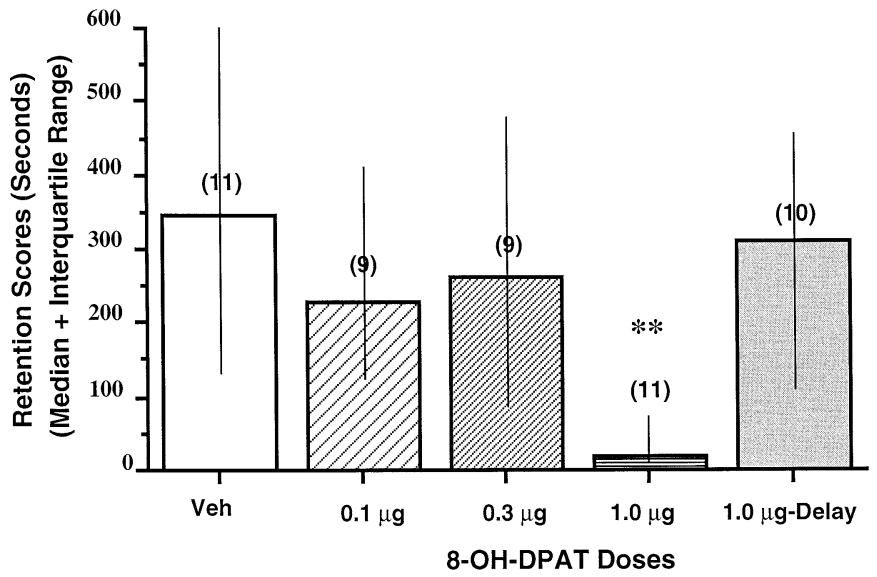

FIG. 2. Post-training intra-amygdala infusion of $1.0 \mu \mathrm{g}$ 8-OH-DPAT impaired 1 -day retention. The vehicle (Veh) or a dose of the drug was infused either immediately or $4 \mathrm{~h}$ (delay) after training. $* * P<0.01$ different from the vehicle group and the $1.0 \mu \mathrm{g}$ delay injection group.

after training $(U=13, P<0.01)$. Rats given $1.0 \mu \mathrm{g}$ buspirone immediately after training or $2.5 \mu \mathrm{g}$ buspirone $4 \mathrm{~h}$ after training did not differ from the controls in retention $(U=58$ and 44, respectively; $P>0.10)$. Rats given post-training infusion of $2.5 \mu \mathrm{g} \mathrm{S}(-) \mathrm{UH}-301$ into the amygdala tended to have retention scores better than the controls, although the difference only approached statistical significance $(U=45,0.05<P<0.075)$. Retention in the group given $\mathrm{S}$ (UH-301 plus buspirone were significantly better than that in the group given $2.5 \mu \mathrm{g}$ buspirone $(U=14, P<0.05)$, while the former group appeared to have poorer retention than the controls, but the difference was not significant $(U=54, P>0.10)$.

\section{Effects of post-training intra-amygdala infusion of 8-OH-DPAT on retention}

This experiment examined whether post-training intra-amygdala infusion of a selective 5- $\mathrm{HT}_{1 \mathrm{~A}}$ agonist, 8-OH-DPAT, would mimic the effect of buspirone. Five groups of rats were used. Four of them received immediate post-training intra-amygdala infusion of vehicle, or $0.1,0.3$ or $1.0 \mu \mathrm{g} 8$-OH-DPAT and the remaining one received intra-amygdala infusion of $1.0 \mu \mathrm{g} 8$-OH-DPAT $4 \mathrm{~h}$ after training. The 1-day retention is shown in Fig. 2. As indicated in the figure, posttraining intra-amygdala infusion of 8-OH-DPAT induced a timedependent and dose-dependent retention deficit; i.e. $1.0 \mu \mathrm{g}$ infused into the amygdala immediately after training impaired retention, while the same dose given $4 \mathrm{~h}$ later had no effect. A oneway ANOva revealed significant differences among the groups $\left[H^{\prime}(4)=14.9, P<0.005\right]$. Paired comparisons indicated that the group receiving $1.0 \mu \mathrm{g} 8-\mathrm{OH}-$ DPAT immediately after training showed lower retention scores than the vehicle controls $(U=13, P<0.002)$ and the group receiving the same treatment $4 \mathrm{~h}$ later $(U=11.5, P<0.003)$. Lower doses of 8 OH-DPAT failed to generate any statistically significant effect.

\section{Effects of post-training intra-amygdala infusion of WAY100635 on retention}

Five groups of rats were trained and tested. They received intraamygdala infusion of vehicle, $0.1,0.5,2.5$ or $10.0 \mu \mathrm{g}$ of the $5-\mathrm{HT}_{1 \mathrm{~A}}$ antagonist WAY100635 immediately after training. Retention tested 1 day later is shown in Fig. 3. As shown in the figure, post-training intra-amygdala infusion of WAY100635 induced biphasic effects on retention. It caused a weak but nonetheless significant enhancement at a low dose, but caused a pronounced impairment at a high dose.

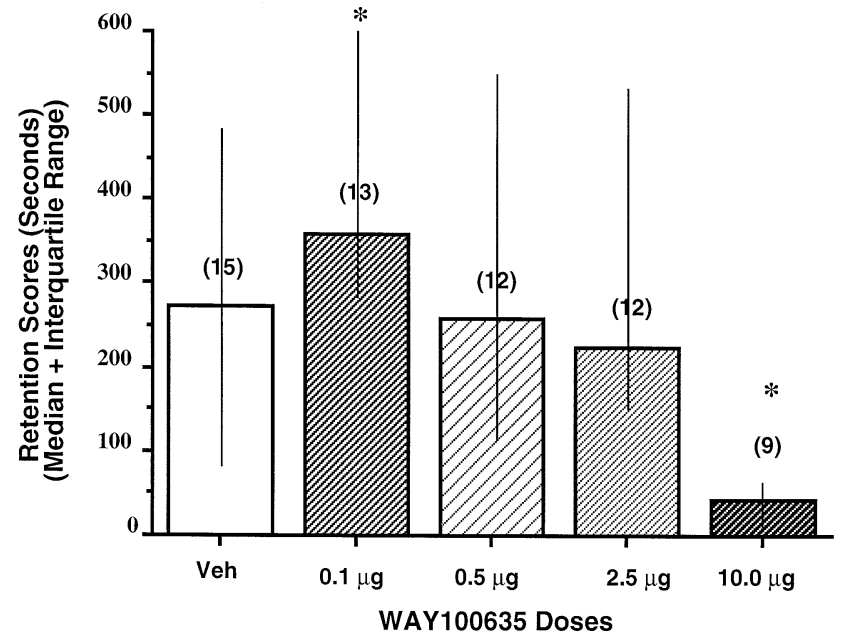

FIG. 3. Intra-amygdala infusion, immediately after training, of vehicle (Veh) or WAY100635 at various doses had biphasic effects on 1-day retention; the $0.1 \mu \mathrm{g}$ dose induced a slight memory enhancement, while $10.0 \mu \mathrm{g}$ induced a profound memory impairment. $* P<0.05$ different from the vehicle group.

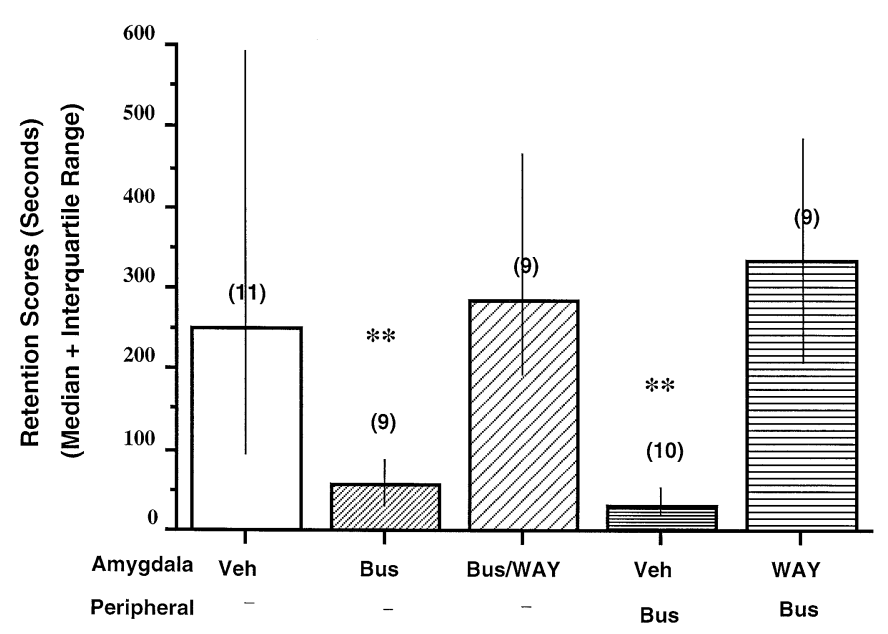

FIG. 4. Post-training intra-amygdala infusion of $2.5 \mu \mathrm{g}$ WAY100635 (WAY) attenuated the amnesic effects of buspirone (Bus) given either systemically $(5.0 \mathrm{mg} / \mathrm{kg}) 30 \mathrm{~min}$ before training or into the amygdala $(2.5 \mu \mathrm{g})$ immediately after training. $* * P<0.01$ different from the vehicle group and the group treated with intra-amygdala infusion of WAY100635.

A oneway ANOVA revealed significant differences among the groups $\left[H^{\prime}(4)=14.8, P<0.01\right]$. Further paired comparisons indicated that rats receiving $0.1 \mu \mathrm{g}$ WAY 100635 had retention scores slightly better than the controls, and the difference was statistically significant $(U=$ 53.5, $P<0.05)$. In contrast, rats receiving $10.0 \mu \mathrm{g}$ WAY 100635 showed retention scores significantly lower than the controls $(U=$ $25, P<0.05)$ and the group receiving $0.1 \mu \mathrm{g}$ WAY100635 $(U=8$, $P<0.001)$. Other doses of WAY 100635 caused no significant effect on retention.

\section{Attenuation of buspirone effects by post-training intra- amygdala infusion of WAY100635}

This experiment examined whether intra-amygdala infusion of WAY100635 would attenuate the amnesic effect of buspirone administered either peripherally or centrally. Five groups of rats were trained and tested. Three groups received, immediately after training, intraamygdala infusion of vehicle, buspirone or buspirone plus WAY100635. The dose was $2.5 \mu \mathrm{g}$ for both drugs. The two other 

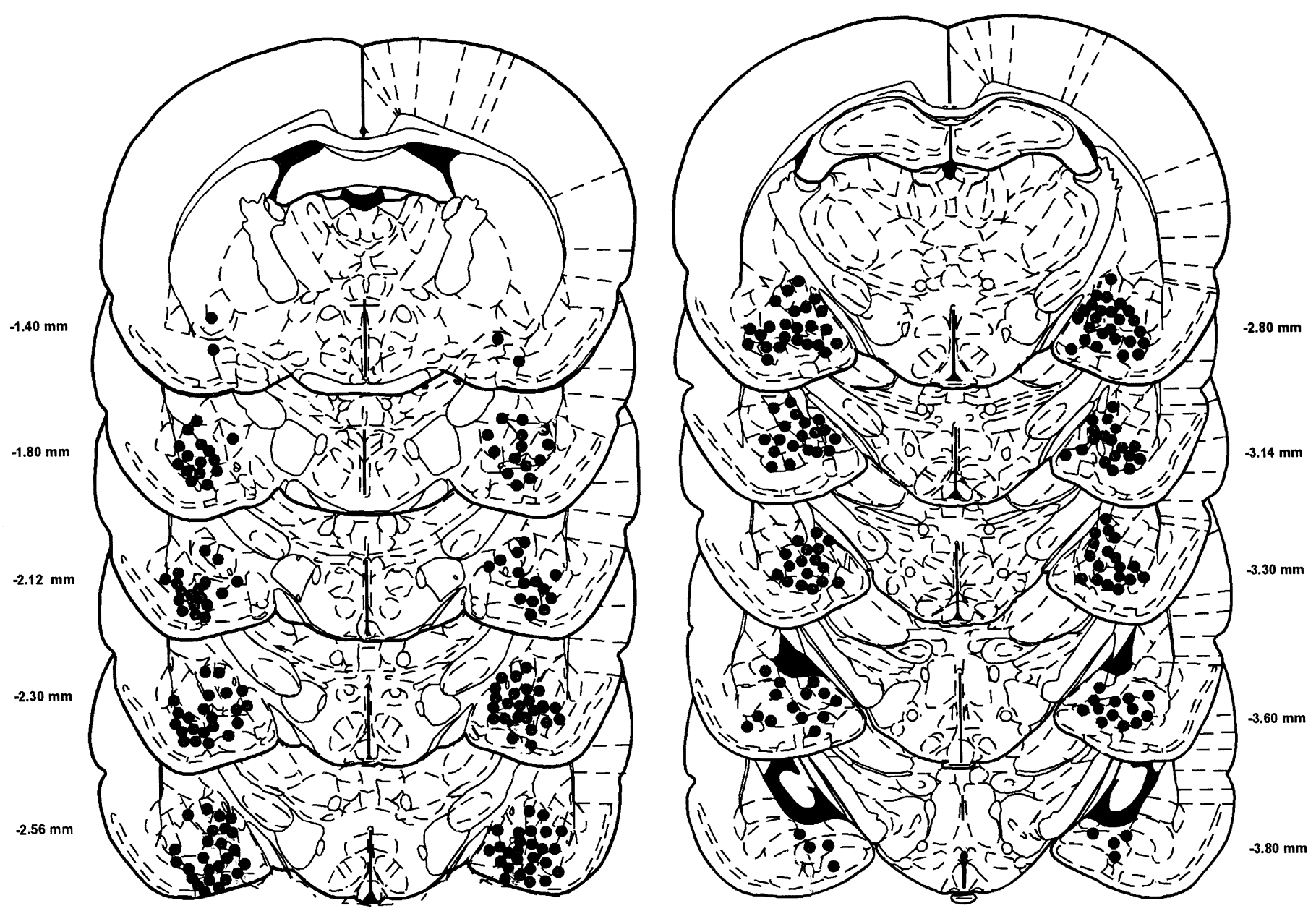

FIG. 5. Distribution of cannula tip positions within the amygdala in the implanted rats, in a series of coronal sections based on the atlas by Paxinos \& Watson (1997).

groups received systemic injections of $5.0 \mathrm{mg} / \mathrm{kg}$ buspirone $30 \mathrm{~min}$ before training and intra-amygdala infusion of either vehicle or $2.5 \mu \mathrm{g}$ WAY100635 immediately after training. The 1-day retention performance shown in Fig. 4 indicates that the $5-\mathrm{HT}_{1 \mathrm{~A}}$ antagonist WAY 100635 readily attenuated the retention impairing effect of buspirone given either systemically or directly into the amygdala. A oneway ANOVA revealed significant differences among the groups $\left[H^{\prime}(4)=21.9, P<0.0005\right]$. Further paired comparisons showed that rats given intra-amygdala infusion of buspirone after training had significantly lower retention scores than the vehicle controls $(U=$ $13, P<0.01)$ and rats receiving intra-amygdala infusion of buspirone plus WAY100635 $(U=7, P<0.01)$. Rats receiving a pretraining systemic injection of buspirone and post-training intra-amygdala infusion of vehicle also had significantly lower retention scores than either the controls $(U=12, P<0.01)$ or rats having a pretraining systemic injection of buspirone plus post-training intra-amygdala infusion of WAY100635 $(U=9, P<0.005)$. The latter two groups did not differ from each other.

\section{Histology}

The distribution of positions of cannula tips in the implanted animals is shown in Fig. 5 on a series of coronal planes compiled from a rat brain atlas by Paxinos \& Watson (1997). As indicated in the figure, the locations of cannula tips were in a widespread area including the basolateral, basomedial, central, cortical and medial nuclei within the amygdala. No apparent relationship was detected between retention performance and the site of infusion within the amygdala.

\section{Discussion}

The major findings of this study can be recapitulated as follows. In the inhibitory avoidance task, pretraining or post-training systemic injections of buspirone induced a dose-dependent retention deficit which was not a state-dependent effect. The effect was probably due to influences of buspirone on memory processing of the shock. Posttraining intra-amygdala infusion of buspirone or 8-OH-DPAT caused a dose- and time-dependent memory deficit. Conversely, post-training intra-amygdala infusion of the 5- $\mathrm{HT}_{1 \mathrm{~A}}$ antagonist WAY-100635 at a nonfacilitating dose attenuated the memory-impairing effect of buspirone administered either systemically or into the amygdala. These findings suggest that buspirone may affect memory formation for aversive experience by acting on the amygdaloid $5-\mathrm{HT}_{1 \mathrm{~A}}$ receptors.

The present result, that pretraining systemic injection of buspirone impaired retention of an inhibitory avoidance response, is consistent with previous ones that buspirone impeded acquisition of an avoidance task in rats (Torres et al., 1995) and a conditioned emotional response in mice (Quartermain et al., 1993). Effects on retention induced by a pretraining treatment might be due to alterations in sensory, motor or motivational factors. However, the fact that the effect of buspirone administered before training could be reproduced by post-training 
injection of the drug, and almost totally reversed by post-training intra-amygdala infusion of a $5-\mathrm{HT}_{1 \mathrm{~A}}$ antagonist, ruled out the involvement of sensory alterations in the observed effect. Further, buspirone appeared not to affect the tendency of the animal to enter the dark compartment, as attested by its lack of effect on entrance latencies during training in the first experiment. Previous results have also shown that pretraining injections of buspirone impaired acquisition or retention in learning tasks requiring motor profiles different from the inhibitory avoidance task, such as the active avoidance task and Morris water maze (Liang et al., 1998). It was thus implausible that influences of buspirone on performance factors would have contributed significantly to the observed amnesic effect.

Responses acquired under one state might not be easily retrieved under a different state (Overton, 1974). Likewise, memory consolidated in different states may be differentially influenced by specific testing conditions during retrieval (Pinheiro \& Wright, 1991), and a previous study has reported a state-dependent effect induced by a post-training treatment (Netto et al., 1991). It was thus possible that inhibitory avoidance memory consolidated under the influence of buspirone was more difficult to retrieve in a nondrug state and the resulting deficit should then be alleviated by pretest injections of buspirone. Yet contrary to this expectation, the present results showed that $2.5 \mathrm{mg} / \mathrm{kg}$ of buspirone given both after training and before testing induced a notably severer, not milder, deficit than that induced by injecting the same dose of drug at either occasion alone. This finding unequivocally rejected the state-dependent hypothesis and was consistent with the previous ones reporting no state-dependency for the effects of buspirone given before training or testing on retention (Rowan et al., 1990; Liang et al., 1998).

A previous study reported, in contrast to our findings, that buspirone given $30 \mathrm{~min}$ before training had no effect on retention in the inhibitory avoidance task (Rowan et al., 1990). The single low dose of buspirone ( $1 \mathrm{mg} / \mathrm{kg})$ and a low cut-off ceiling score (300 s) adopted in that study may have prevented it from detecting the effects seen in our study, i.e. a mild deficit induced by a moderate dose of buspirone $(2.5 \mathrm{mg} / \mathrm{kg})$ and a prominent deficit induced by a higher dose $(5.0 \mathrm{mg} / \mathrm{kg})$. The present results further showed that post-training injections of buspirone caused a time-dependent memory deficit: The impairment diminished as application of the drug was delayed after the training experience. Such data strongly support the notion that buspirone acted on memory formation processes per se. If posttraining buspirone indeed affects memory consolidation and thus renders a weaker trace, one would expect a greater retention deficit in tests with extended retention intervals. This was exactly what has been shown by a recent study from this laboratory (Liang et al., 1998).

The influence of buspirone and other 5 - $\mathrm{HT}_{1 \mathrm{~A}}$ drugs on the retention of aversive learning tasks (Rowan et al., 1990; Carli et al., 1992) suggests that they may affect memory processing of emotional events. On the other hand, the impairing effect of buspirone or 8-OH-DPAT on performance in the water maze implies that the drug may act on the hippocampus to affect memory of spatial and/or contextual cues (Carli et al., 1995a; McNaughton \& Morris, 1992). The present study used the inhibitory avoidance task to test these two views, because its one-trial training paradigm was suitable for application of posttraining treatments that affect memory processes per se. In a training trial of the inhibitory avoidance task, a rat learned, among other things, about the configuration of a light-dark alley and association of shock with the dark compartment. The combination of such knowledge fosters the dark-avoidance behaviour in retention tests. The present study showed that when rats acquired knowledge about the alley context and aversiveness of the dark side sequentially in two successive days, they were still able to combine them, and showed avoidance as strong as that observed in the normal onetrial training procedure. Informal observation showed that retention remained similar between the two groups 1 month after training, ruling out any difference concealed in the ceiling scores of the 1-day test. Withholding either phase of training led to poor retention, suggesting that both phases of training were essential for the inhibitory avoidance behaviour to appear in the test.

As memory processing in the two training phases was independently manipulated, buspirone produced a marked effect on retention when injected after the shock-training phase. The findings strongly suggest that buspirone affected memory processing of emotional events, which was critical for the rat to display avoidance behaviour in testing. Such results are consistent with previous ones showing that post-training treatments are able to affect retention in aversive learning tasks (Scavio et al., 1992) including conditioned freezing responses to auditory cues (Rudy, 1996). In contrast, the present study was not able to find a significant effect of buspirone on memory processing of context cues. This lack of effect is unlikely to occur because the context knowledge had little role in the formation of the avoidance memory, as withholding such training resulted in poor retention. An earlier study has also suggested that $5-\mathrm{HT}_{1 \mathrm{~A}}$ agonists do not affect spatial memory per se (Riekkinen et al., 1995). While these results were inconsistent with the notion that buspirone may act on the hippocampus to affect memory processes of contextual or spatial cues, they can not rule out the possibility completely, because such an effect may appear in more sensitive tasks. Further, it is also possible that buspirone or other 5- $\mathrm{HT}_{1 \mathrm{~A}}$ agonists, even if not affecting the formation of memory for contextual or spatial cues per se, may interfere with the association of such cues with emotional significance, a function that may also engage the hippocampus (Phillips \& LeDoux, 1992). This possibility, in accordance with the available data showing that intrahippocampal infusion of buspirone or other $5-\mathrm{HT}_{1 \mathrm{~A}}$ drugs affects memory in certain tasks (Carli et al., 1995a; Liang et al., 1998), should be pursued in the future with more sensitive behavioural paradigms.

No previous studies provided evidence concerning the central site at which buspirone may act to affect memory. The suppressing effect of buspirone or some 5- $\mathrm{HT}_{1 \mathrm{~A}}$ agonists on certain types of unconditioned fear or anxiety responses might involve presynaptic receptors in the median or dorsal raphe nucleus (Schreiber \& De Vry, 1993; File et al., 1996). However, these nuclei are apparently not essential for buspirone to suppress expression of conditioned fearpotentiated startle (Davis et al., 1988). On the basis of the finding that buspirone affected both the emotional component of inhibitory avoidance memory and a critical role of the amygdala in such memory (LeDoux, 1995), this study examined involvement of the amygdala in effects of buspirone on retention of the inhibitory avoidance response. Rats receiving post-training intra-amygdala infusion of vehicle appeared to have lower retention than rats receiving i.p. injections of vehicle. This impairment could be due to minor damages caused by chronic implantation and/or vehicle infusion into the amygdala as previous results have shown that nonimplanted controls can have better performance than implanted controls in the inhibitory avoidance task (Liang et al., 1982). In comparison with this less than perfect retention performance of controls, $2.5 \mu \mathrm{g}$ buspirone infused into the amygdala after training still induced a time-dependent retention deficit, implying that the amygdala is a site for buspirone to exert its influence on memory of aversive events.

Post-training intra-amygdala infusion of the $5-\mathrm{HT}_{1 \mathrm{~A}}$ agonist $8-\mathrm{OH}-$ DPAT $(1.0 \mu \mathrm{g})$ caused a retention deficit similar to that induced by buspirone, raising the possibility that both drugs acted on $5-\mathrm{HT}_{1 \mathrm{~A}}$ receptors in the amygdala to modulate memory. This conjecture 
gained extra support from the results that intra-amygdala infusion of 5-HT $\mathrm{HA}_{1 \mathrm{~A}}$ antagonists $\mathrm{S}(-) \mathrm{UH}-301$ or WAY100635 attenuated the memory-impairing effect of buspirone administered peripherally or directly into the amygdala. Because S(-)UH-301 attenuated the deficit at a dose tending to enhance memory by itself, the observed attenuation could be a result of two opposite effects added together but irrelevant to mechanisms. However, WAY100635 did attenuate the buspironeinduced retention deficit at a dose not having an effect of its own. These results suggest that peripherally administered buspirone may exert its influences on memory through binding to the amygdaloid 5$\mathrm{HT}_{1 \mathrm{~A}}$ receptors. A previous study reported that the effect of buspirone in blocking expression of conditioned fear was not related to its action on $5-\mathrm{HT}_{1 \mathrm{~A}}$ receptors (Davis et al., 1988). Whether buspirone may affect formation and expression of emotional memory through different receptor substrates would be an interesting issue for further investigation.

The observed amnesic effect of 5- $\mathrm{HT}_{1 \mathrm{~A}}$ agonists raises a question of whether endogenously released serotonin may normally play an inhibitory role on memory. This issue could be addressed by examining whether post-training administration of $5-\mathrm{HT}_{1 \mathrm{~A}}$ antagonists would enhance retention. Previous findings showed that WAY100135 had no effect in affecting memory (Carli et al., 1995b). In contrast, in this study we found that immediate post-training infusion of WAY 100635 into the amygdala induced a biphasic effect. A low dose $(0.1 \mu \mathrm{g})$ caused a weak memory enhancement but a high dose $(10.0 \mu \mathrm{g})$ caused a marked deficit. Another $5-\mathrm{HT}_{1 \mathrm{~A}}$ antagonist $\mathrm{S}(-) \mathrm{UH}-301(2.5 \mu \mathrm{g})$ also tended to enhance memory, although the effect only approached significance. The results are consistent with a recent finding that a 5- $\mathrm{HT}_{1 \mathrm{~A}}$ antagonist NAN190 (1-(2-methoxyphenyl)-4[4-(2-phthalimido)butyl]piperzine hydrobromide) infused into the CA1 region facilitated learning and memory in a shuttle-box task (Ohno \& Watanabe, 1997). Such findings suggest that endogenous 5-HT may indeed be released during learning experiences and exert some sort of inhibition on memory formation. Whether the impairing effect of WAY100635 at a high dose was due to nonspecific action of the drug remains to be clarified.

The present findings were unable to address the issue of the specific amygdala nuclei in mediating the observed effects because the cannula tips were distributed widely within the amygdala and their location bore no apparent relationship with retention scores. According to a previous study, $1 \mu \mathrm{L}$ of infusion volume spread into an area of $\approx 2.0 \mathrm{~mm}$ in diameter (Myers, 1966), which would encroach into most of the amygdala nuclei. The basolateral and central amygdala nuclei have been implicated in different aspects of aversive conditioning (LeDoux, 1995; Killcross et al., 1997b). Application of 5-HT or 8-OH-DPAT to amygdala slices depressed excitatory synaptic transmission and depolarization-evoked $\mathrm{Ca}^{2+}$ influx in neurons of the basolateral nuclei (Cheng et al., 1998), even though they have only low densities of 5-HT $\mathrm{H}_{1 \mathrm{~A}}$ receptors (Kia et al., 1996). High and moderate densities of 5- $\mathrm{HT}_{1 \mathrm{~A}}$ receptors were found, respectively, in the cortical nuclei (Kia et al., 1996) and the basomedial or medial nuclei (Pompeiano et al., 1992). Early studies have shown that these nuclei are sensitive to the disruptive effect of low current electrical stimulation on memory in the inhibitory avoidance task (Bresnahan \& Routtenberg, 1972; Kesner \& Conner, 1974; Gold et al., 1977). Thus they could mediate the effect of $5-\mathrm{HT}_{1 \mathrm{~A}}$ drugs on memory.

It should be noted that the amygdala might not be the only substrate mediating the effect. The septohippocampal system has been implicated in fear and anxiety functions (Gray, 1982). Previous studies found that memory was impaired by post-training infusion of 8-OH-DPAT into the lateral septum (Lee et al., 1992) or pretest infusion of buspirone into the hippocampus (Liang et al., 1998).
Drugs infused into the amygdala might spread along the cannula shaft into the striatum (Kesner et al., 1981), but such diffusion is unlikely to account for the present effect, because few $5-\mathrm{HT}_{1 \mathrm{~A}}$ receptors were detected in the striatum (Pompeiano et al., 1992). The piriform cortex and ventral hippocampus adjacent to the amygdala do, however, have a moderate-to-high density of 5 - $\mathrm{HT}_{1 \mathrm{~A}}$ receptors (Pompeiano et al., 1992), and the effect could be caused by diffusion of drugs into these regions. If this had been the case, rats with cannulae within the amygdala, but adjacent to these structures, should have shown greater effects. Yet, as stated in the results, no relationship was detected between various infusion sites within the amygdala and retention performance. A smaller infusion volume should be used in future studies to discriminate the roles of specific amygdala nuclei and their adjacent structures in mediating the effects of $5-\mathrm{HT}_{1 \mathrm{~A}}$ drugs on memory.

The neuronal mechanisms underlying the memory modulating effect of $5-\mathrm{HT}_{1 \mathrm{~A}}$ drugs remain to be elucidated. It has been proposed that with regard to cognitive functions, the serotonergic system interacts with cholinergic activity (Cassel \& Jeltsch, 1995), which in certain structures such as the amygdala plays a modulatory role on memory (McGaugh et al., 1993; Everitt \& Robbins, 1997). Alternatively, activating $5-\mathrm{HT}_{1 \mathrm{~A}}$ receptors may impair memory by affecting neuronal plasticity in the amygdala, such as long-term potentiation which was shown to be associated with formation of emotional memory (Rogan et al., 1997). Regardless of the mechanism, given that associative learning presumably plays an important role in our daily fear or anxiety reactions to otherwise neutral stimuli, the ability of buspirone or other anxiolytics to prevent the formation or expression of fear associations may contribute positively to their therapeutic efficacy, rather than being a mere deleterious side-effect.

\section{Acknowledgements}

The author would like to express his appreciation for the assistance from the students involved in part of this study and Dew-Yu Chen for the illustrations. Special thanks go to $\mathrm{Mr} \mathrm{Wu}-\mathrm{Yen} \mathrm{Yu}$ for his continuous and excellent service to our facilities in the animal laboratory. This study was supported in part by grants NSC 86-2413-H002-012 and NSC 87-2413-H002-012 from the National Science Council, Taiwan, R.O.C.

\section{Abbreviations}

5-HT, serotonin, 5-hydroxytryptamine; 8-OH-DPAT, 8-hydroxy-2-(di- $n$-propylamino)tetralin; Bus, buspirone; NAN190, 1-(2-methoxyphenyl)-4[4-(2phthalimido)butyl]piperzine hydrobromide; S(-)UH-301, S(-)-5-fluoro-8hydroxy-2-dipropylamino-1,2,3,4-tetrahydronaphthalene hydrochloride; Veh, vehicle (group); WAY100135, N-tert-butyl-3-4-(2-methoxyphenyl)piperazin1-yl-2-phenylpropanamide dihydrochloride; WAY100635, N-(2-(4-(2methoxyphenyl)-1-piperazinyl)-N-(2-pyridyl)cyclohexane carboxamine maleate.

\section{References}

Aggleton, J. (1992) The Amygdala. Neurobiological Aspects of Emotion, Memory, and Mental Dysfunction. Wiley, New York.

Bass, E.W. Jr, Means, L.W. \& McMillen, B.A. (1992) Buspirone impairs performance of a three-choice working memory water escape task in rats. Brain Res. Bull., 28, 455-461.

Bosker, F.J., Klompmakers, A. \& Westenberg, H.G. (1997) Postsynaptic 5$\mathrm{HT}_{1 \mathrm{~A}}$ receptors mediate 5-hydroxytryptamine release in the amygdala through a feedback to the caudal linear raphe. Eur. J. Pharmacol., 333, $147-157$

Bresnahan, E. \& Routtenberg, A. (1972) Memory disruption by unilateral low level sub-seizure stimulation of medial amygdaloid nucleus. Physiol. Behav., 9, 513-525.

Buhot, M.-C. (1997) Serotonin receptors in cognitive behaviors. Curr. Opin. Neurobiol., 7, 243-254. 
Cao, B.-J. \& Li, W.-P. (1994) Antagonism of clonidine antinociception by buspirone and 1-(2-pyrimidinyl)-piperazine. Eur. J. Pharmacol., 259, 75-78.

Carli, M., Luschi, R., Garofalo, P. \& Samanin, R. (1995a) 8-OH-DPAT impairs spatial but not visual learning in a water maze by stimulating $5-\mathrm{HT}_{1 \mathrm{~A}}$ receptors in the hippocampus. Behav. Brain Res., 67, 67-72.

Carli, M., Luschi, R. \& Samanin, R. (1995b) (S)-WAY100135, a 5-HT $1 \mathrm{~A}$ receptor antagonist, prevents the impairment of spatial learning caused by intra-hippocampal scopolamine. Eur. J. Pharmacol., 283, 133-139.

Carli, M., Tranchina, S. \& Samanin, R. (1992) 8-hydroxy-2-(di-n-propylamino) tetralin, a $5-\mathrm{HT}_{1 \mathrm{~A}}$ receptor agonist, impairs performance in a passive avoidance task. Eur. J. Pharmacol., 211, 227-234.

Cassel, J.-C. \& Jeltsch, H. (1995) Serotonergic modulation of cholinergic function in the central nervous system: Cognitive implications. Neuroscience, 69, 1-41.

Cheng, L.-L., Wang, S.-J. \& Gean, P.-W. (1998) Serotonin depresses excitatory synaptic transmission and depolarization-evoked $\mathrm{Ca}^{2+}$ influx in rat basolateral amygdala via 5-HT $1 \mathrm{~A}$ receptors. Eur. J. Neurosci., 10, 2163-2172.

Cole, J.C. \& Rodgers, R.J. (1994) Ethological evaluation of the effects of acute and chronic buspirone treatment in the murine elevated plus-maze test: Comparison with haloperidol. Psychopharmacology, 114, 288-296.

Coplan, J.D., Wolk, S.I. \& Klein, D.F. (1995) Anxiety and serotonin1A receptor. In Bloom, F.E. \& Kupfer, D.J. (eds.), Psychopharmacology: the Fourth Generation of Progress. Raven Press, New York, pp. 1301-1310.

Curran, H.V. (1990) Benzodiazepines, memory and mood: a review. Psychopharmacology, 105, 1-8,

Davis, M., Cassella, J.V. \& Kehne, J.H. (1988) Serotonin does not mediate anxiolytic effects of buspirone in the fear-potentiated startle paradigm: comparison with 8-OH-DPAT and ipsapirone. Psychopharmacology, 94 $14-20$

De Almeida, R.M. \& Lucion, A.B. (1997) 8-OH-DPAT in the median raphe, dorsal periaqueductal gray and corticomedial amygdala nucleus decreases, but in the medial septal area it can increase maternal aggressive behavior in rats. Psychopharmacology, 134, 392-400.

Everitt, B.J. \& Robbins, T.W. (1997) Central cholinergic systems and cognition. Ann. Rev. Psychol., 48, 649-684.

File, S.E., Gonzalez, L.E. \& Andrews, N. (1996) Comparative study of preand postsynaptic 5-HT $\mathrm{HT}_{1 \mathrm{~A}}$ receptor modulation of anxiety in two ethological animal tests. J. Neurosci., 16, 4810-4815.

Giral, P., Soubrie, P. \& Puech, A.J. (1987) Pharmacological evidence for the involvement of 1-(2-pyrimidinyl)-piperazine (1-PmP) in the interaction of buspirone or gepirone with noradrenergic systems. Eur. J. Pharmacol., 134, 113-116.

Gold, P.E., Hankins, L.L. \& Rose, R.P. (1977) Time-dependent posttrail changes in the localization of amnestic electrical stimulation sites within amygdala in rats. Behav. Biol., 20, 32-40.

Gray, J.A. (1982) The Neurobiology of Anxiety: an Inquiry into the Functions of the Septo-Hippocampal System. Oxford University Press, New York.

Harder, J.A., Maclean, C.J., Alder, J.T., Francis, P.T. \& Ridley, R.M. (1996) The 5-HT $1 \mathrm{~A}$ antagonist, WAY100635, ameliorates the cognitive impairment induced by fornix transection in the marmoset. Psychopharmacology, 127, $245-225$.

Harvey, J.A. (1996) Serotonergic regulation of associative learning. Behav. Brain Res., 73, 47-50.

Herremans, A.H.J., Hijzen, T.H., Olivier, B. \& Slangen, J.L. (1995) Serotonergic drug effects on a delayed conditional discrimination in the rat: involvement of the $5-\mathrm{HT}_{1 \mathrm{~A}}$ receptor in working memory. J. Psychopharmacol., 9, 242-250.

Kant, G.J., Meininger, G.R., Maughan, K.R., Wright, W.L., Robinson, T.N \& Neely, T.M. (1996) Effects of the serotonin receptor agonists 8-OHDPAT and TFMPP on learning as assessed using a novel water maze. Pharmacol. Biochem. Behav., 53, 385-390.

Kehne, J.H., Cassella, J.V. \& Davis, M. (1988) Anxiolytic effects of buspirone and gepirone in the fear-potentiated startle paradigm. Psychopharmacology, 94, 8-13.

Kesner, R.P. \& Conner, H.S. (1974) Effects of electrical stimulation of rat limbic system and midbrain reticular formation upon short- and long-term memory. Physiol. Behav., 12, 5-12.

Kesner, R.P., Partlow, L.M., Bush, L.G. \& Berman, R.F. (1981) A quantitative regional analysis of protein synthesis inhibition in the rat brain following localized injection of cycloheximide. Brain Res., 209, 159-176.

Kia, H.K., Brisoregueil, M.J., Miquel, M.C., Daval, G., Riad, M., El Mestikawy, S., Hamon, M. \& Verge, D. (1996) Immunocytochemical localization of 5$\mathrm{HT}_{1 \mathrm{~A}}$ receptors in the rat central nervous system. J. Comp. Neurol., 365 289-305.

Killcross, A.S., Stanhope, K.J., Dourish, C.T. \& Piras, G. (1997a) WAY100635 and latent inhibition in the rat: selective effects at preexposure. Behav. Brain Res., 88, 51-57.

Killcross, S., Robbin, T.W. \& Everitt, B.J. (1997b) Different types of fearconditioned behavior mediated by separate nuclei within amygdala. Nature, 388, 377-380.

Korneyev, A.Y. (1997) The role of the hypothalamic-pituitary-adrenocortical axis in memory-related effects of anxiolytics. Neurobiol. Learn. Mem., 67, $1-13$

Lazosky, A.J. \& Britton, D.R. (1991) Effects of 5-HT 1A $_{\text {A }}$ receptor agonists on CRF-induced behavior. Psychopharmacology, 104, 132-136.

eDoux, J.E. (1995). Emotion: a clue from the brain. Ann. Rev. Psychol., 46, 209-235

Lee, E.H.Y., Chen, H.Y., Lin, W.R., Shiu, W.H. \& Liang, K.C. (1992) Retention of an inhibitory avoidance response in rats is enhanced by fluoxetine and impaired by $8-\mathrm{OH}-\mathrm{DPAT}$ injected into the lateral septum. Physiol. Behav., 51, 681-688.

Liang, K.C., Hon, W. \& Davis, M. (1994) Pre-and post-training infusion of N-Methyl-D-aspartate receptor antagonists into the amygdala impair memory in an inhibitory avoidance task. Behav. Neurosci., 108, 241-253.

Liang, K.C., McGaugh, J.L., Martinez, J.L., Jr, Jensen, R.A., Vasquez, B.J. \& Messing, R.B. (1982) Posttraining amygdaloid lesions impair retention of an inhibitory avoidance response. Behav. Brain Res., 4, 237-249.

Liang, K.C., Tsui, K.-Y., Tyan, Y.-M. \& Chaing, T.-Z. (1998) Buspirone impaired acquisition and retention in avoidance tasks: Involvement of the hippocampus. Chin. J. Physiol., 41, 33-44.

Lister, S., Pearce, J.M., Butcher, S.P., Collard, K.J. \& Foster, G.A. (1996) Acquisition of conditioned inhibition in rats is impaired by ablation of serotonergic pathways. Eur. J. Neurosci., 8, 415-423.

Martinez, J.A. \& Bueno, L. (1991) Buspirone inhibits corticotropin-releasing factor and stress-induced cecal motor response in rats by acting through 5$\mathrm{HT}_{1 \mathrm{~A}}$ receptors. Eur. J. Pharmacol., 202, 379-383.

McGaugh, J.L. (1989) Dissociating learning and performance: Drug and hormone enhancement memory storage. Brain Res. Bull., 23, 339-345.

McGaugh, J.L., Introini-Collison, I.B., Cahill, L., Castellano, C., Dalmaz, C., Parent, M. \& Williams, C. (1993) Neuromoudlatory systems and memory storage: Role of the amygdala. Behav. Brain Res., 58, 81-90.

McMillen, B.A., Matthews, R.T., Sanghera, M.K., Shepard, P.D. \& German, D.C. (1983) Dopamine receptor antagonism by the novel antianxiety drug, buspirone. J. Neurosci., 3, 733-738.

McNaughton, N. \& Morris. R.G.M. (1992) Buspirone produces a dose-related impairment in spatial navigation. Pharmacol. Biochem. Behav., 43, 167-171.

Myers, R.D. (1966) Injection of solutions into cerebral tissue: relation between volume and diffusion. Physiol. Behav., 1, 171-174.

Netto, C.A., Valente, J.T., Borges-Sobrinho, J.B., Lasevitz, J. \& Tomaz, C.A. (1991) Reversal of retrieval impairment caused by retroactive interference on a two-way active avoidance task in rats. Behav. Neural Biol., 55, 114-122.

Nishimura, H., Tanaka, M., Tsuda, A. \& Gondoh, Y. (1993) Atypical anxiolytic profile of buspirone and a related drug, SM-3997, in a modified forced swim test employed straw suspension. Pharmacol. Biochem. Behav., 46, 647-665.

Ohno, M. \& Watanabe, S. (1997) Behavioral responses to the 5-HT $1 \mathrm{~A}$ receptor antagonist NAN190 injected into rat CA1 hippocampal area. Gen. Pharmacol., 28, 435-441.

Overton, D.A. (1974) Experimental methods for the study of state-dependent learning. Fed. Proc., 33, 1800-1813.

Paxinos, G. \& Watson, C. (1997) The Rat Brain in Stereotaxic Coordinates. 3rd Compact edn. Academic Press, San Diego.

Pazos, A. \& Palacios, J.M. (1985) Quantitative autoradiographic mapping of serotonin receptors in the rat brain. I. Serotonin-1 receptors. Brain Res., 346, 205-230.

Phillips, R.G. \& LeDoux, J.E. (1992) Differential contribution of amygdala and hippocampus to cued and contextual fear conditioning. Behav. Neurosci., 106, 274-285.

Pinheiro, A.D. \& Wright, D.C. (1991) Naloxone eliminates passive avoidance retention deficits produced by pretest exposure to novelty in rats. Behav. Neural Biol., 55, 270-288.

Pompeiano, M., Palacios, J.M. \& Mengod, G. (1992) Distribution and cellular localization of mRNA coding for $5-\mathrm{HT}_{1 \mathrm{~A}}$ receptor in the rat brain: Correlation with receptor binding. J. Neurosci., 12, 440-453.

Quartermain, D., Clemente, J. \& Shemer, A. (1993) 5-HT HA $_{1}$ agonists disrupt memory of fear conditioning in mice. Biol. Psychiatry, 33, 247-254.

Riblet, L.A., Taylor, D.P., Eison, M.S. \& Stanton, H.C. (1982) Pharmacology and neurochemistry of buspirone. J. Clin. Psychiatry, 43, 11-18.

Riekkinen, M., Sirvio, J., Toivanen, T. \& Riekkinen, P. Jr (1995) Combined treatment with a $5 \mathrm{HT}_{1 \mathrm{~A}}$ receptor agonist and a muscarinic acetylcholine 
receptor antagonist disrupts water maze navigation behavior. Psychopharmacology, 122, 137-146.

Rogan, M.T., Staubli, U.V. \& LeDoux, J.E. (1997) Fear conditioning induces associative long-term potentiation in the amygdala. Nature, 390, 604-607. Rowan, M.J., Cullen, W.K. \& Moulton, B. (1990) Buspirone impairment of performance of passive avoidance and spatial learning tasks in the rat. Psychopharmacology, 100, 393-398.

Rudy, J.W. (1996) Scopolamine administered before and after training impairs both contextual and auditory-cue fear conditioning. Neurobiol. Learn. Mem. 65, 73-81.

Santucci, A.C., Knott, P.J. \& Haroutunian, V. (1996) Excessive serotonin release, not depletion, leads to memory impairments. Eur. J. Pharmacol., 295, 7-17.

Scavio, M.J., Clift, P.S. \& Wills, J.C. (1992) Posttraining effects of amphetamine, chlorpromazine, ketamine, and scoplamine on the acquisition and extinction of the rabbit conditioned nictitating membrane response. Behav. Neurosci., 106, 900-908.

Schreiber, R. \& De Vry, J. (1993) Neuronal circuits involved in the anxiolytic effects of the 5- $\mathrm{HT}_{1 \mathrm{~A}}$ receptor agonists 8-OH-DPAT, ipsapirone and buspirone in the rat. Eur. J. Pharmacol., 249, 341-353.
Sirvio, J., Riekkinen, P., Jakala, P. Jr \& Riekkinen, P.J. (1994) Experimental Studies on the role of serotonin in cognition. Prog. Neurobiol., 43, 363-379.

Torres, C., Morales, A., Candido, A. \& Maldonado, A. (1995) Differential effect of buspirone and diazepam on negative contrast in one-way avoidance learning. Eur. J. Pharmacol., 280, 277-284.

Treit, D., Robinson, A., Rotzinger, S. \& Pesold, C. (1993) Anxiolytic effects of serotonergic interventions in the shock-probe burying test and the elevated plus-maze test. Behav. Brain Res., 54, 23-34.

Tunnicliff, G., Eison, A.S. \& Taylor, D.P. (1991) Buspirone: Mechanisms and Clinical Aspects. Academic Press, San Diego.

Vanderwolf, C.H. (1987) Near-total loss of learning and memory as a result of combined cholinergic and serotonergic blockade in the rat. Behav. Brain Res., 23, 43-57.

Walker, D.L. \& Davis, M. (1997) Anxiogenic effects of high illumination levels assessed with the acoustic startle response in rats. Biol. Psychiatry, 42, 461-471

Wenk, G., Hughey, D., Boundy, V., Kim, A., Walker, L. \& Olton, D. (1987) Neurotransmitters and memory: Role of cholinergic, serotonergic, and noradrenergic systems. Behav. Neurosci., 101, 325-332. 